\title{
ISLAMIC EDUCATION AND SOCIAL MEDIA TRANSFORMATION IN PANDEMIC ERA: CHALLENGES AND OPPORTUNITIES IN INDONESIA
}

\author{
Miftahul Ulum \\ State Islamic Institute of Ponorogo \\ Email: ulum@iainponorogo.ac.id \\ Asmak Ab Rahman \\ Academy of Islamic Studies University of Malaya Malaysia \\ Email: asmak@um.edu.my \\ Shinta Maharani \\ State Islamic Institute of Ponorogo \\ Email:maharani@iainponorogo.ac.id \\ Agus Purnomo \\ State Islamic Institute of Ponorogo \\ Email:purnomo@iainponorogo.ac.id
}

\begin{abstract}
Religious learning in the pandemic era was carried out through social media, such as Facebook, Whatsapp, Twitter, and Instagram. YouTube is transformed into the premier medium of teaching. For students and the millennial generation, social media provides many conveniences. However, on the other hand, it becomes a problem in itself, especially for parents in presenting education that is full of values, during a struggle for the free flow of information and communication. The paper aims to analyze the transition of learning media in education, from conventional offline models to online via social media, and to prove the impact of using social media on students or the millennial generation. Qualitative methods are used to analyze data. The findings of this paper indicate that education during a pandemic, reading printed literature, is also carried out via the internet. Social media has a significant impact on students or the millennial generation, so efforts to strengthen values are needed. Social media brings together the main actors in education; parents, academics, government, social media, and regulation.
\end{abstract}


Abstrak: Pembelajaran agama di era pendemi dilakukan melalui media sosial, seperti Facebook, Whatsapp, Twitter, dan Instagram. YouTube ditransformasikan menjadi media utama dalam pengajaran. Bagi siswa dan generasi milenial, media sosial menyediakan banyak kemudahan. Namun pada sisi lain, menjadi problem tersediri, terutama orang tua dalam menghadirkan pendidikan yang sarat dengan nilai, di tengahtengah pertarungan arus informasi dan komunikasi yang bebas. Tujuan dari paper ini adalah: untuk menganalisis peralihan media pembelajaran dalampendidikan, dari model konvensional luring menuju daring online melalui media sosial, dan membuktikan dampak penggunaan media ssosial tersebut bagi siswa atau generasi milenial. Metode kualitatif digunakan guna menganalisis data. Temuan dari paper ini menunjukkan bahwa pendidikan pada masa pandemi, selain dengan cara menbaca literatur cetak, jugadilakukan melalui internet. Media sosial sangat berdampak terhadap siswa atau generasi milenial, sehingga diperlukan upaya penguatan nilai.Media sosial menyatukan aktor-aktor utama dalampendidikan, yaitu; orang tua, akademisi, pemerintah, media sosial, dan regulasi itu sendiri.

Keywords: pandemic era; Islamic education; social media

\section{INTRODUCTION}

Indonesia has a lot of local cultures. It is rich in values and norms prevailing in society. Modernization culture is carried by social media, copied by our young generation, from free sex and drug abuse. Loss of national identity is the crucial thing that will face. Thus, it is a need to implement the values of religion in a social system. The family becomes an essential element in socialization to children to become a vital element in the community. High technological development must be balanced with the ability of people to deal with complete information. Reinforce family values as the foundation of a society. It is where values and norms are disseminated to all community members, run all the points above to be our reference in facing this wave of modernization.

Abuddin Nata said that there are at least eight diseases that afflict modern society. First is the dis integration between science (specializations that are too rigid) that amounted to the sense human minds tend to educate the public. Second, personality split (split personality) s e like the result of a life modeled by science that is too specialized and did not have the character and values of divinity. The third is the shallow sense of faith, piety, and humanity resulting from the ration a listic and individualistic life. Fourth, materialistic relationship patterns as a result of life after the world are excessive. Fifth tends to justify any means as a result of the understanding of hedonism that engulfs life. Sixth, he is easily stressed and frustrated due to being too trusting and proud of his abilities without being accompanied by his trust and trust in Allah's 
provisions. Seventh, feelings of alienation in the crowd (lonely), an individualistic nature, and the eighth loss of self-esteem and future result from evil deeds. ${ }^{1}$ These eight things result from a life that has been so far hegemonies by a global culture dominated by social media. Everything is instant and individually s tic, which is the implications of global change.

In this regard, education has a very strategic position and role in dealing with these problems. Therefore, a correct understanding of Islamic education, its nature, and its characteristics must not lose its direction and orientation in its development. Incorrect understanding of Islamic education will undoubtedly harm the future generation of this nation, so education is not a solution to the problem but becomes the problem itself.

\section{RESEARCH METHOD}

This study used a qualitative research approach. This research used books as the primary source. By describing and explaining the data collected from the book - without intervening in interpreting the data, the data would not lose its authenticity.

The data sources in this study were the primary and secondary data sources. The primary data sources were Al-Qur'an and Hadits related to Islamic education. Moreover, the secondary data sources were books related to Islamic Education and social media.

The data were collected through the documentation. Since it employed literature research, the data collection techniques were done by reading the statutory products studied in this study as data. The data analysis systematically tracks and organizes data collected to increase understanding of these materials to be presented to others. Thus, this research's data analysis is content analysis, an analysis by presenting the data, presenting data, and analyzing its contents.

\section{RE-UNDERSTANDING ISLAMIC EDUCATION COMPREHENSIVELY}

Muhaimin interpreted Islamic education with three things; (1) education in (history) Islam, namely education that was born and developed along with the dynamics and development (history) of Islam; (2) Islamic perspective education means education in the view of the Koran and al-Hadith as the primary source of Islamic teachings; and (3) Islamic religious education that means Islam as a way of life or a way of life for the believer. ${ }^{2}$

All three show the breadth of discussion and the scope of Islamic education itself, so caution is needed to question and study Islamic education itself. P

\footnotetext{
1 Abuddin Nata, Manajemen Pendidikan: Mengatasi Kelemahan Pendidikan Islam di Indonesia (Jakarta: Kencana, 2003), 22.

2 Muhaimin, Wacana Pengembangan Pendidikan Islam (Surabaya: PSAPM, 2003), 23-24.
} 
Education religious question is religious education in families, schools, madrasas, mosque committees, and non-formal.

Conceptually, the I slamic education course will lead to three terms commonly used: tarbiyah, study groups, and ta' dib. The use of each term has many implications. All three became s course that never culminates in an agreement on the term most appropriately used to interpret Islamic education. Ainain,_al-Abrasyi,_ Mursyi promoted the concept of tarbiyah; Yunus ${ }^{3}$ use the word tarbiyah to sense education.

The term al-Tarbiy a $h$ is more appropriate in the context of Islamic education than al-Ta'lim. Both have fundamental differences. Tarbiyah means to educate, while ta'lim means to teach. Educating means to prepare learners in all sorts of ways, use their energy and talents well, and achieve a perfect life in the community. Therefore, education includes education of reason, citizenship, physical, moral, and social. While al-Ta'lim, only one of the means of education is manifold, stated in the following text. ${ }^{4}$

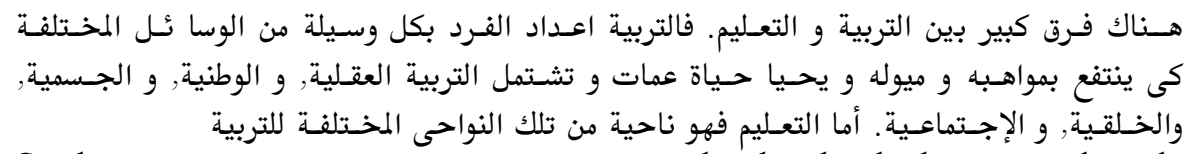

Study groups are one means among means al-tarbiyah. al-talim precisely only conveys the science and knowledge into the minds and memories that fill the children with science and art problems. Therefore, Saranac means in Ta'lim there are three, namely: teachers, students, and science knowledge are. It is stated in the following text. ${ }^{5}$

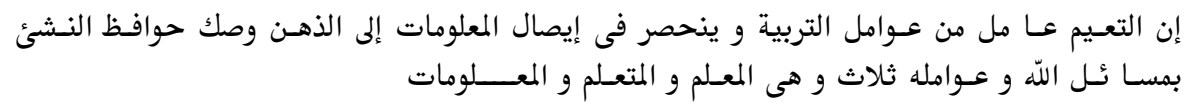

The concept of ta'lim, ${ }^{6}$ resting his opinion on the verses of the Qur'an "As we have sent you who read our verses to you, sanctify you, and teach you alKi tab and al-Hikmah, and teach you what is not yet known. (Surat al-Baqarah [2]: 151)"

"O our Lord, send them an Apostle from among them who will read to them Your verses and teach them al-Kitab (al-Qur'an) and al-Hikmah and purify them. Verily, Thou are the Mighty, the Wisest. (Surat al-Baqarah [2]: 129)"

Syed Muhammad Naquib al-Attas said that Islamic education was alta'dib, al-Tarbiyah, and al-Ta'lim, Al-Attas. Based on his analysis of the semantic

${ }^{3}$ Mahmud Yunus, al-Tarbiyah was al-Ta'lim. Saturn Dalam al-Tarbiyah was al-Ta'lim juz Awal C (Gontor: Darussalam Press, t.t.), 3.

${ }^{4}$ al-Abrasy, Rūh al-Tarbiyah al-Islāmiyah.

5 Yunus, al-Tarbiyah was al-Ta'lim. Saturn Dalam al-Tarbiyah was al-Ta'lim juz Awal C, 3.

${ }^{6}$ Abdul Fattah Jalal, Min al-Ușūl at-Tarbiyah fí al-Islām (Mesir: Dar al-Kutub al-Misriyah, 1977), 15-25. 
concept of the Hadith of the Messenger of Allah, narrated by Ibn Mas'ud when the Qur'an itself described as God's invitation to attend a banquet on earth and is strongly encouraged to take part in it by having the proper knowledge. ${ }^{?}$

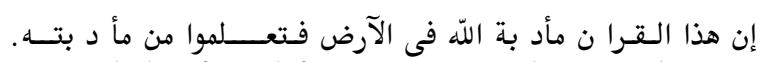

Meaning: Indeed, the Qur'an is a dish of God for man on earth; it is whoever studied it, meaning his study of the cuisine (HR. Ibn Mas'ud).

The word translated as educating by al-Atta is "addaba," the meaning is "ta'dib," and means education. In the original and basic meaning, "addaba" means "the inviting to a banquet" (invitation to a banquet). The idea of a banquet implies that a host is a noble person. At the same time, the attendees are thought to deserve respect to be invited because they are qualified and educated people. They are expected to adapt, both in their behavior and circumstances. Therefore, a correct understanding of Islamic education in general and in specific contexts in the family becomes very important. The intended meaning is the complete understanding of both the concept. It is because there is a hidden value from parent to child. So, the conception is intact, and how to view a comprehensive manner. It will give a clear picture of the object. According to contraception and context, the debate around him should be kept in perspective in Islamic education.

\section{ISLAMIC EDUCATION THROUGH SOCIAL MEDIA}

Social media, such as Facebook, Whatsapp, Twitter, and Instagram, YouTube, have been transformed into primary transmission media in the digital age. Learning does not need to take as long as before and requires them away from home for millennials. Social media provides various things instantly on their smartphones. Still, for families, the content may be more fragmented for limited space and time to access information on social media. Its value has also changed for inhuman contacts. It brings opportunities and challenges to understand and present family welfare through social media, bearing in mind the dynamics and change for the millennial generation, primarily dependent on social media. Social media aims to realize that future generations literate in science and technology (science and technology) have faith and piety on the one hand and the other hand. Printing a millennial generation who is a religious expert is the primary goal of family welfare; studying religion, understanding religion, practicing

7 Muhammad al-Naquibal-Attas is an expert in language, philosophy, and education. Since October 4, 1991, he has been confirmed as Director of ISTAC (International Institute of Islamic Thought and Civilization), an International Institute of Islamic Thought at the S2 and S3 program at the International Islamic University Malaysia. See more, Halim Soebahar, Wawasan Baru Pendidikan Islam (Pasuruan: PT Garoeda Buana Indah, 1992), 2. 
religious knowledge, and teaching it to others as a form of commitment and responsibility are parents' ideals and initial goals. ${ }^{8}$

In today's development, there are alternative places to study religion that are similar to the family or accommodate some of its systems, so that social media emerges and is born with Instagram, YouTube, Facebook, WhatsApp, and others. Within this framework, there are undoubtedly different understandings of educating and preparing generations within Islamic education. Of course, problems in social media different from real life. When each family member establishes good communication between family members, welfare can be achieved. It should concern that learning and social media accessible by family members is restricted than at least, which will minimize problems and issues in Islamic education.

\section{SOCIAL MEDIA}

Social media is a tool used by people to interact with each other by creating, sharing, and exchanging information and ideas in a virtual network and community. ${ }^{9}$ Social media is the media used by individuals to be social or become social online by sharing content, news, photos. Social media covers various new media platforms and implies inclusion-for example, Friend Feed, Facebook, and others generally considered social networks. The idea is that various media platforms have a social component and are a medium of public communication. ${ }^{10}$

Kaplan and Heinlein said that there are six types of social media. ${ }^{11}$ It divides collaborative projects, which allows for collaboration in content creation carried out by several users simultaneously, for example, Wikipedia. Blogs are personal web and generally display date-stamped entries in chronological form. A prevalent type of blog is a text-based blog. Content communities have the primary goal of sharing media content among users, including text, photos, videos, and PowerPoint presentations. Users do not need to create a personal profile page. Social networking sites allow users to connect by creating personal profile information and inviting friends and colleagues to access profiles and send emails and instant messages. Profiles generally include photos, videos, audio files, blogs, and others. Examples; Facebook, MySpace, and Google+; Virtual game worlds are a platform that replicates the environment in a three-

8 Imam Zarkasyi, Diktat Pekan Perkenalan PM. Gontor (Gontor: Trimurti Press, 1986), 1; Harun Nasution dan Tim IAIN Syarif Hidayatullah, Ensiklopedi Islam Indonesia (Jakarta: Djambatan, 1992), 771.

9 McGraw Hill Dictionary (United States of America, 2020), 3.

${ }^{10}$ Mark Hopkins, "Mass media in the Soviet Union," Pegasus 1 (1970): 5.

${ }^{11}$ Andreas M. Kaplan and Michael Haenlein, "Users of the world, unite! The challenges and opportunities of Social Media," Business horizons Volume 53, no. 1 (Februari 2010): 5968. 
dimensional form that makes users appear in the form of personal avatars and interact according to game rules. Virtual social worlds allow inhabitants to freely choose their behavior and live in a virtual world similar to real life.

\section{SOCIAL MEDIA CHARACTERISTICS}

Social media has several characteristics: The quality of the distribution of messages through social media has various high variations, ranging from inferior quality to very high quality, depending on the content; The reach of social media technology is decentralized, not hierarchical; Frequency represents the number of times users spend accessing social media each day; Accessibility illustrates the ease of social media for users to access; Uses describe anyone who has internet access can do various things using social media such as posting digital photos, writing online; Immediately, describe the time it takes for social media users to communicate with other people instantly.

\section{SOCIAL MEDIA IMPACT ON PANDEMIC ERA Social Media on the pandemic Era}

A recent survey shows that the time people spend on social media globally has increased by an average of almost $60 \%$ over the past seven years. The Londonbased research company Global Web Index analyzed data from 45 of the world's largest internet markets. It is estimated that each person allocated to social media increased from 90 minutes per day in 2012 to 143 minutes in the first three months of 2019. However, there is a wide variation in the use of social media at the regional and national levels. In Latin America, the biggest social media user, the time spent every day reaches 212 minutes. The lowest average duration at the regional level comes from North America (116 minutes). The Philippines is a country whose citizens spend the most time on social media: 241 minutes per day, while Japan only reached 45 minutes. ${ }^{12}$

\section{Decrease}

However, perhaps surprisingly, the survey of 1.8 million people also revealed that the duration of social media playing remained or declined in almost half the country's list (20 countries). Global Web Index stated that the data showed that "many internet users have a better awareness of the time they spend looking at the screen." Internet users now spend more than six hours online every day. Onethird of that time is devoted to social media. It continuous observation around personal incidents of actual figures and content moderation responsibilities; the level of social media presence in our daily lives has become a hot topic. The amount of daily time we spend on social media is one of the most visible

12 "The digital trends to know for 2018," global web index website (blog), March 2020. 
indicators of its presence. The growth of tools supporting digital activity further enhances the visibility of that presence. Among the countries surveyed, Thailand recorded the most significant decrease in daily use of social media: the average duration dropped from 194 minutes to 171 minutes between 2018 and 2019. In Vietnam, daily use of social media is reduced by 10 minutes compared to last year's record. Malaysia, Belgium, Ghana, and the United States also showed sharp declines. However, in most of the countries surveyed, the results were different. The increase in playing time on social media has increased rapidly in several countries. ${ }^{13}$

\section{Super application}

The social media landscape is unique. 'Super applications' - social media applications that play a far broader role than social media platforms in Western understanding - are prevalent. It is not only done. It allows users to connect with friends, but it also does everything, from paying various bills, booking restaurants, ordering taxis, and paying for items in stores. Increased playing time for social media seems to support specific demographic groups: people aged 16 to 24 . They spend the most time online every day - Global Web Index records their daily use of social media on average by almost 180 minutes in 2018. The higher the country's overall usage time is from younger countries with emerging markets, the "duration of playing social media" ranking. Young users remain the most involved overall compared to other age groups. They will always be the most involved. ${ }^{14}$

\section{Health}

Experts have warned that the longer duration of activity in front of the screen is associated with several mental health problems. Research shows that people who spend more time on social media are less happy. Excessive use of technology can cause problems. In extreme cases, it is related to depression, accidents, and even death. These potential risks seem to trigger behavioral changes: "digital health" applications, which serve to limit or calculate the duration of our screen use, are increasingly popular. ${ }^{15}$

There are no standard hours regarding how long someone should spend online. The World Health Organization (WHO) issued instructions for the first screen duration last April - intended for children under five. A University of

\footnotetext{
13 "The digital trends to know for 2018."

14 "The digital trends to know for 2018."

${ }^{15}$ Ashley V. Whillans dkk., "From Misperception to Social Connection: Correlates and Consequences of Overestimating Others' Social Connectedness," Personality and Social Psychology Bulletin Vol 43, no. 12 (2017): 1696-1711.
} 
Pennsylvania study published last December found that limiting social media use to 30 minutes per day resulted in a significant reduction in feelings of loneliness and depression in a group of 143 students who took part in social media use experiments. However, some experts believe that the problem is more complicated than that. Social media is very diverse - different sites offer different features. Therefore, it makes it very difficult to generalize the impact of social media.

In a society, a solid foundation is a family, where all elements of values, norms, and culture are applied. The family is also a cycle of the socialization process to shape the personality of the community. The pandemic means that the problems become complicated; the education and community structure's challenges get many obstacles that could be damaging. In this 21 st century, mass media and social media's critical role is essential as new social fabric values. Social media has become a part of social life. Currently, there is no single activity that cannot be separated from social media.

The development of information technology has made many positive sides. Still, it cannot deny the negative impact of social media development on a family. Society will be substantial if the structure of Islamic education is stable. An indication of a society with a solid Islamic education foundation is where the order of values and norms goes well, consistently applying religion. The most important thing is the socialization process that runs by the excellent culture of a community. The ease of accessing social media is making society very apathetic. Not only that, the process of diffusion and assimilation will happen quickly, with all the effects of this globalization, automatically damage the function and role of a family. This change will also threaten the order of society. However, the most terrible impact is also the erosion of religion. The community becomes consumptive due to globalization's pop culture, the destruction of the religious identity, the tenuous role of family members, and many more.

\section{CONCLUSION}

Social media undeniably bring pop culture and liberalism culture, which poisoned second world countries like Indonesia to adopt their culture. As a result, many young people were contaminated with free culture. One way to stem the flow of modernization is to maintain the family religion in the community. One of the small things is by implementing cooperation culture as a characteristic of Indonesian society. It could reduce the apathy of modern society. It instills the values and norms for children such as kiss their parents' hands, implement a system to respect older people, say greetings when we visit or meet someone, constantly applying a system of tolerance to everyone. Besides maintaining family traditions, it also aims to socialize the role of the family in the community. 
In religion, these values and norms are used as guidelines in strengthening a family's wellbeing.

We cannot deny that our children will be raised side by side with the rapid flow of technology; the children will be more daring to ask search engines than ask us directly. The children will be more receptive to socialization from a variety of electronic devices than their parents. Children will be fonder of telling stories to their social media than with their parents, and hedonist culture will be entrenched due to society's consumptive culture. The role of Islamic education to improve all these conditions then. Finally, Indonesia, a nation, has its own identity, a mature country, and a religious country. 


\section{REFERENCES}

Abrasy, Muhammad Athiyah al-. al-Tarbiyah al-Islāmiyah wa falsafatuhā. Mesir: Isa al-Baby, 1975.

ㄴ. Rūh al-Tarbiyah al-Islāmiyah. 1 ed. Kairo: Dar Ihya' al-Kutub al-Arabiyah, 1950.

'Ainain, Ali Khalīl Abu al. Falsafah al-Tarbiyah fî al-Qur'ān al-Karīm. Beirut: Dar al-Fikri al'Araby, 1980.

Hopkins, Mark. "Mass media in the Soviet Union." Pegasus 1 (1970): 5.

Jalal, Abdul Fattah. Min al-Ușūl at-Tarbiyah fî al-Islām. Mesir: Dar al-Kutub alMisriyah, 1977.

Kaplan, Andreas M., dan Michael Haenlein. "Users of the world, unite! The challenges and opportunities of Social Media." Business horizons Volume 53, no. 1 (Februari 2010): 59-68.

McGraw Hill Dictionary. United States of America, 2020.

Muhaimin. Wacana Pengembangan Pendidikan Islam. Surabaya: PSAPM, 2003.

Mursyi, Muhammad Munir. al-Tarbiyah al-Islāmiyah Ușūluhā wa Tațawwuruhā fí al-Bilād al-'Arabiyah. Mesir: Dar al-Ma'ārif, 1987.

Nasution, Harun, dan Tim IAIN Syarif Hidayatullah. Ensiklopedi Islam Indonesia. Jakarta: Djambatan, 1992.

Nata, Abuddin. Manajemen Pendidikan: Mengatasi Kelemahan Pendidikan Islam di Indonesia. Jakarta: Kencana, 2003.

Soebahar, Halim. Wawasan Baru Pendidikan Islam. Pasuruan: PT Garoeda Buana Indah, 1992.

global web index website. "The digital trends to know for 2018," Maret 2020.

Whillans, Ashley V., Chelsea D. Christie, Sarah Cheung, Alexander H. Jordan, dan Frances S. Chen. "From Misperception to Social Connection: Correlates and Consequences of Overestimating Others' Social Connectedness." Personality and Social Psychology Bulletin Vol 43, no. 12 (2017): 1696-1711. 
196 Miftahul Ulum dkk, Islamic Education and Social Media

Yunus, Mahmud. al-Tarbiyah was al-Ta'lim. Saturn Dalam al-Tarbiyah was alTa'lim juz Awal C. Gontor: Darussalam Press, t.t.

Zarkasyi, Imam. Diktat Pekan Perkenalan PM. Gontor. Gontor: Trimurti Press, 1986. 